\title{
Perbandingan Terapi Topikal Natrium Klorida 0,9\% dengan Minyak Biji Jintan Hitam (Nigella sativa) terhadap Waktu Transpor Mukosilliar Hidung Penderita Rinitis Alergi
}

\author{
Fatimah Qonitah Diyanah ${ }^{1}$, M. Nurrizki Haitamy ${ }^{1}$, Anis Kusumawati ${ }^{1}$, Oke Kadarullah ${ }^{1}$ \\ ${ }^{1}$ Fakultas Kedokteran Universitas Muhammadiyah Purwokerto
}

\begin{abstract}
Allergic rhinitis occurs $40 \%$ from the world population. In Indonesia, it tends to increase every year. Exposure to allergens that stimulate the symptoms of rhinitis can disrupt the process of nasal clearance and increase the time of Mucociliary Transport (TMS). $\mathrm{NaCl} 0.9 \%$ nasal spray is one of supportive therapy of rhinitis allergic. Black Seed Oil is known as an antihistamine and anti-inflammatory that can improve the symptoms of rhinitis allergic and nasal TMS. To determine the ratio of topical therapy by $\mathrm{NaCl} 0.9 \%$ with Black Seed Oil on TMS time of rhinitis allergic. This is a clinical trial involving 10 research subjects. The subjects are selected using a SFAR questionnaire. The selected subjects are divided into 2 groups treated with topical $\mathrm{NaCl} 0.9 \%$ and Black Seed Oil for 14 days. Before and after therapy the TMS time is checked with saccharin test. Data on time difference between TMS before and after therapy are analyzed with Paired T-Test. Data on time comparison of TMS between $\mathrm{NaCl} 0.9 \%$ and Black Seed Oil are analyzed with Independent T-Test. Result: TMS time before and after therapy with $\mathrm{NaCl} 0.9 \%$ and Black Seed Oil each has $\mathrm{p}>0.05$. Comparison of TMS time reduction in both treatments shows a non-significant difference $(\mathrm{p}=0.831)$. There are no significant differences in $\mathrm{TMS}$ of $\mathrm{NaCl}$ $0.9 \%$ and Black Seed Oil therapy to patients with rhinitis allergic.
\end{abstract}

Keywords: Rhinitis Allergic, Mucociliary Transport, $\mathrm{NaCl} 0.9 \%$, Black Seed Oil

\section{Abstrak}

Rinitis alergi terjadi $40 \%$ pada populasi dunia, di Indonesia cenderung meningkat setiap tahunnya. Paparan allergen yang menstimulus gejala rinitis dapat menganggu proses bersihan hidung dan meningkatkan waktu Transpor Mukosilliar (TMS). Semprot hidung $\mathrm{NaCl}$ 0,9\% merupakan salah satu terapi suportif rinitis alergi. Minyak Biji Jintan Hitam diketahui sebagai antihistamin dan antiinflamasi yang dapat memperbaiki gejala rinitis alergi dan TMS hidung. Mengetahui perbandingan terapi topikal $\mathrm{NaCl}$ 0,9\% dengan Minyak Biji Jintan Hitam terhadap waktu TMS hidung penderita rinitis alergi. Penelitian ini merupakan clinical trial dengan melibatkan 10 subyek penelitian. Subyek dipilih dengan menggunakan kuesioner SFAR. Subyek yang terpilih dibagi menjadi 2 kelompok yang diterapi dengan topikal $\mathrm{NaCl}$ 0,9\% dan Minyak Biji Jintan Hitam selama 14 hari. Sebelum dan sesudah terapi dilakukan pemeriksaan waktu TMS dengan tes sakarin. Data perbedaan waktu TMS hidung sebelum dan sesudah terapi dianalisis dengan Paired T-Test. Data perbandingan waktu TMS hidung antara kelompok $\mathrm{NaCl} 0,9 \%$ dan Minyak Biji Jintan Hitam dianalisis dengan Independent T-Test. Waktu TMS hidung sebelum dan sesudah terapi pada kelompok $\mathrm{NaCl}$ 0,9\% dan Minyak Biji Jintan Hitam masing-masing memiliki $p>0,05$ Perbandingan penurunan waktu TMS pada kedua terapi menunjukkan perbedaan yang tidak bermakna $(p=0,831)$. Terdapat perbedaan yang tidak bermakna pada waktu TMS hidung terapi topikal $\mathrm{NaCl} 0,9 \%$ dan minyak biji jintan hitam pada penderita rinitis alergi.

Kata Kunci : Rinitis alergi, transport mukosilliar $\mathrm{NaCl}$ 0,9\%, minyak biji jintan 


\section{PENDAHULUAN}

Rinitis alergi dan Rinosinusitis kronik terjadi lebih dari $30 \%$ pada populasi dunia ${ }^{1}$ Penderita rinitis alergi mengalami gangguan mukosa hidung, inflamasi dan edem yang dapat menganggu pergerakan silia sehingga mengganggu transpor mukosilliar (TMS) hidung secara lokal2. Rinitis alergi memiliki pengaruh terhadap perkembangan anak-anak dan remaja di sekolah serta memiliki korelasi dengan gangguan ansietas dan depresi yang dapat mempengaruhi prestasi dalam belajar dan berkurangnya produktifitas $^{3 .} \quad$ Rinitis alergi dapat mempengaruhi kualitas hidup penderitanya secara signifikan. Kejadian rinitis alergi pada mahasiswa sebesar $41,4 \%^{4}$.

Terapi medikamentosa pada rinitis alergi dapat menggunakan topikal maupun oral dari steroid, antihistamin, dekongestan serta terapi cuci hidung untuk mengurangi gejala pada pasien rinitis alergi serta memperbaiki transpor mukosilliar hidung ${ }^{5}$.

$\mathrm{NaCl}$ 0,9\% sebagai larutan fisiologis yang biasa digunakan sebagai cairan pencuci hidung diketahui memiliki efek mukolitik serta Jintan hitam merupakan salah satu pengobatan Rasulullah (Thibbun-Nabawi) yang memiliki banyak manfaat untuk kesehatan, anti-inflamasi, anti-kanker, immunomodulator, antimikroba, dan bronkodilator yang diharapkan dapat memperbaiki transport mukosilliar hidung penderita rhinitis alergi

\section{BAHAN DAN METODE}

Penelitian ini merupakan jenis penelitian clinical trial dengan rancangan penelitian pretestposttest design. Prosedur penelitian ini sudah disetujui oleh Komisi Etik Fakultas Kedokteran Universitas Muhamamdiyah Purwokerto.

\section{Pengambilan Sampel}

Total seluruh subyek adalah 10 subyek yang dibagi dalam 2 kelompok terapi yang dipilih dengan metode simple random sampling, sehingga masing-masing kelompok terapi tediri dari 5 subyek. Pemilihan subyek dilakukan di Fakultas KedokteranUniversitas Muhammadiyah Purwokerto dengan menggunakan kuesioner SFAR (Score for Allergy Rhinitis) . Subyek yang terpilih adalah yang memiliki skor kuseioner SFAR 27 .Subyek yang sudah terpilih dilakukan tessakarin untuk menghitung waktu transpor mukosilliar (TMS) sebelum dan sesudah terapi.

Tes sakarin dilakukan di Rumah Sakit Islam Purwokerto. Subyek yang sudah menjalankan tes sakarin, diberikan terapi topikal berupa semprot hidung $\mathrm{NaCl} 0,9 \%$ sebanyak 5 subyek dan terapi topikal berupa Minyak Biji Jintan Hitam sebanyak 5 subyek. Terapi dilakukan selama 14 hari. Terapi yang dilakukan berupa semprot hidung sebanyak 3 kali dalam satu hari. Pada setiap lubang hidung disemprot sebanyak 2 kali pada pagi hari, 2 kali pada siang hari dan 2 kali pada malam hari.

\section{Analisis Data}

Data waktu transpor mukosilliar sebelum dan sesudah terapi pada masing-masing terapi dianalisis dengan uji paired $t$-test sedangkan data penurunan waktu transport mukosilliar pada keduanya, dibandingkan dengan uji analisis menggunakan Nilai $\mathrm{p}<0,05$ digunakan untuk menentukan level signifikasi.

\section{HASIL}

Hasil dari subyek yang didiagnosis rhinitis alergi menggunakan kuesioner SFAR 
yaitu 6 perempuan dan 4 orang laki-laki yang dapat dilihat pada gambar 4.1. Waktu transport mukosilliar (TMS) hidung pada sebelum dan sesudah terapi $\mathrm{NaCl}$ 0,9\% terdapat penurunan waktu TMS setelah dilakukan terapi. Perbedaan antara waktu TMS sebelum dan sesudah terapi $\mathrm{NaCl} 0,9 \%$ ini berbeda namun tidak bermakna yaitu $p=0.324$ ( $p>0.05)$ hal ini menunjukkan bahwa waktu TMS mengalami penurunan tetapi tidak signifik. Hasil perhitungan dengan paired t-test dapat dilihat pada tabel 4.2 .

Hasil pemeriksaan waktu TMS hidung pada sebelum dan sesudah terapi dengan minyak biji jintan hitam menunjukkan adanya openurunan waktu TMS namun tidak bermajna yaitu $\mathrm{p}=0.334$ ( $\mathrm{p}>0.05)$. Hasil perhitungan dengan paired t-test dapat dilihat pada tabel 4.3.

Waktu transport mukosilliar hidung pada terapi $\mathrm{NaCl}$ 0.9\% dan Minyak Biji Jintan Hitam dibandingkan, dan didapatkan $p>0.05$ atau terdapat perbedaan yang tidak bermakna pada penurunan waktu transport mukosilliar hidung pada kedua terapi yaitu $p=0.831 \quad(p>0.05)$. Hasil perhitungan dapat dilihat pada tabel 4.4

\section{DISKUSI}

Hasil penelitian ini menunjukkan bahwa terdapat 10 orang subyek penelitian, didapatkan 4 orang subyek laki-laki (45\%) dan 6 orang subyek perempuan $(55 \%)$. Perempuan cenderung lebih banyak menderita rinitis alergi dibandingkan lakilaki ${ }^{7}$ Perempuan juga memiliki resiko alergi lebih besar daripada laki-laki dikarenakan faktor hormonal yaitu hormon estrogen yang ada pada perempuan. Hormon estrogen pada perempuan dapat merangsang produksi dari Th2 sehingga menstimulus pengeluaran $\operatorname{IgE}$ dan terjadi reaksi dari autoantigen yang menstimulus pengeluaran histamin sebagai respon dari reaksi hipersensitivitas tipe $1^{8}$ Sseorang ibu menderita atopi, maka akan diturunkan kepada seluruh anak laki-lakinya sedangkan kepada anak perempuannya hanya sebagai carrier. Hal ini berbeda apabila riwayat alergi terjaadi pada Ayah, maka anak laki- laki akan memiliki kemungkinan alergi $50 \%$ dan anak perempuannya tidak akan mengalami atopi dan carrie $^{9}$

Hasil penelitian ini menunjukkan rerata waktu TMS sebelium dilakukan terapi dengan $\mathrm{NaCl} 0,9 \%$ yaitu $(7,582 \pm 1,574)$ dan rerata waktu TMS setelah dilakukan terapi selama 14 hari $(5,876$

$\pm 3,237)$. Hasil ini membuktikan bahwa adanya penurunan waktu TMS setelah dilakukan terapi dengan $\mathrm{NaCl} 0,9 \%$. Hal tersebut diperkuat dengan hasil paired t-test yang menunjukkan adanya perbedaan yang tidak bermakna antara rerata jumlah bakteri pada kedua kelompok $p=0,324(p>0,05)$.

Pemberian $\mathrm{NaCl}$ menyebabkan

keadaan

hiperosmolar pada saluran pernafasan sehingga terjadi pelepasan kalsium dan prostaglandin E2 (PGE2) dari intraseluler dan meningkatkan pergerakan silia. Larutan salin hipertonik ini juga memilliki efek mukolitik dan antibakteri juga dapat mengurangi edema mukosa ${ }^{10}$ Suarez, 2012 menyatakan bahwa transport ion dan cairan epitel pada saluran nafas, menentukan komposisi volume

cairan permukaan saluran nafas/ASL (Airway Surfaceliquid) dan ASL ini sangat mempengaruhi transport mukosilliar, semakin banyak cairan dipermukaan saluran nafas maka semakin lama waktu yang dibutuhkan dalam proses transport mukosilliar. Gerakan transepitel dipengaruhi oleh ion terutama natrium, kalium 
dan bikarbonat, sehingga dapat mengakibatkan perbaikan mukosilliar apabila dilakukan terapi dengan menggunakan $\mathrm{NACl}^{11}$

Hasil penelitian ini menunjukkan rerata waktu TMS sebelium dilakukan terapi dengan Minyak Biji Jintan Hitam yaitu $(7,094 \pm 3,538)$ dan rerata waktu transport mukosilliar $\mathrm{h}$ setelah dilakukan terapi selama 14 hari $(5,810 \pm 3,676)$ Ha.l ini membuktikan bahwa adanya penurunan waktu TMS setelah dilakukan terapi dengan Minyak Biji Jintan Hitam . Hal tersebut diperkuat dengan hasil paired t-test yang menunjukkan adanya perbedaan yang tidak bermakna antara rerata jumlah bakteri pada kedua kelompok yaitu $p=0.334(p>0,05)$.

Pemberian terapi semprot hidung dengan Minyak Biji Jintan Hitam juga memberikan perbaikan waktu transport mukosilliar hidung pada penelitian ini. Kandungan Jintan hitam terhadap imunoterapi secara signifikan meningkatkan proses fagositosis dan aktivitas PMN intraseluler pada pasien dengan rinitis alergi. Jintan hitam juga menghambat COX dan 5-lipoksigenase jalur metabolisme asam arakidonat dan menurunkan sintesis tromboksan dan leukotrin dikarenakan leukotrin adalah mediator kuat yang dalam penyakit alergi termasuk histamin pada rinitis alergi yang berperan dalam reaksi hipersensitivitas langsung, sehingga temuan di atas dapat menjelaskan mekanisme Jintan Hitam dalam mengobati alergi. Kandungan nigellone dalam jintan hitam dapat menurunkan kadar IgE dan hitungan eosinofil. Timokuinon dan nigelone dalam jintan hitam dapat mencegah pelepasan histamin dari makrofag ${ }^{12}$

Hasil penelitian ini menunjukkan rerata penurunan waktu TMS pada terapi $\mathrm{NaCl} 0,9 \%$ adalah $(1,706 \pm 3,398)$ dan rerata penurunan waktu TMS pada terapi Minyak Biji Jintan Hitam adalah
$(1,284 \pm 2,618)$. Hal ini diperkuat dengan Independent t-test dan didapatkan hasil $p=$

$0.831(p>0.05)$ yang menunjukkan terdapat perbedaan penurunan waktu TMS pada kedua terapi tetapi tidak bermakna.

Hal ini sejalan dengan penelitian Oysu, 2014

yang menyatakan bahwa tidak adanya perbedaan yang bermakna antara terapi Minyak Biji Jintan Hitam dengan $\mathrm{NaCl}$ 0,9\% terhapat waktu transport mukosilliar hidung pada pasien tua yang memiliki gejala gangguan hidung. ${ }^{13}$ Kanter, 2006 menjelaskan dalam penelitiannya bahwa terapi topikal dengan menggunakan minyak biji jintan hitam lebih efektif sebagai antihistamin dibandingkan terapi sistemik, hal ini menunjukkan adanya potensi untuk menghambat pengeliuaran leukotriene ${ }^{14}$ Kandungan nigellone dalam jintan hitam dapat menurunkan kadar IgE dan hitungan eosinofil. Timokuinon dan nigelone dalam jintan hitam dapat mencegah pelepasan histamin dari makrofag ${ }^{12}$ Wienkotter, 2008 menjelaskan bahwa kandungan nigelon dalam minyak biji jintan hitam dapat meningkatkan transpor mukosilliar sedangkan timokuinone tidak memiliki efek yang sama ${ }^{15}$ Kim, 2005 menyatakan bahwa larutan salin isotonik diyakini sebagai larutan yang paling fisiologis terhadap morfologi seluler epitel hidung yang dapat meningkatkan availabilitas adenosine triphosphate pada aksonema silia sehingga terjadi peningkatan ciliary beat frequency ${ }^{16}$

Gejala seperti rinore, hidung gatal dan hidung tersumbat menunjukkan perbaikan setelah dilakukan terapi dengan menggunakan minyak biji jintan hitam kecuali gejala pada mata yang hanya mampu membaik dengan terapi sistemik $^{12}$ 
Penurunan gejala gangguan hidung yang lebih bermakna pada pemberian terapi Minyak Biji Jintan Hitam dibandingkan $\mathrm{NaCl}$ 0,9\%. ${ }^{13}$ Berbeda dengan penelitian Kalus, 2003 menjelaskan bahwa pemberian Minyak Biji Jintan Hitam pada pasien rinitis alergi lebih bermakna meningkatkan gejala rinitis alergi dibandingkan placebo ${ }^{17}$

Penelitian ini memiliki keterbatasan yaitu sedikitnya subyek dalam penelitian ini yang belum bisa mewakili jumlah dari populasi. Beberapa subyek penelitian mengeluhkan aroma minyak biji jintan hitam namun masih bersedia mengikuti penelitian hingga selesai dan beberapa subyek juga mengeluhkan respon yang tidak diinginkan sesaat setelah dilakukan semprot hidung dengan minyak biji jintan hitam, sehingga perlu dievaluasi mengenai kandungan dan aroma minyak biji jintan hitam yang berpengaruh pada rinitis alergi.

\section{KESIMPULAN}

1. Terdapat perbedaan yang tidak bermakna pada penurunan waktu transpor mukosilliar hidung pada terapi topikal $\mathrm{NaCl}$ 0,9\% dengan Minyak Biji Jintan Hitam.

2. Terdapat perbaikan transport mukosilliar hidung pada masing-masing terapi.

\section{UCAPAN TERIMA KASIH}

Kepada Fakultas Kedokteran Universitas Muhammadiyah Purwokerto yang sudah memberikan dukungan dalam pembuatan artikel ini dan memberikan izin penggunaan Laboratorium Biomedis Fakultas Kedokteran Universitas Muhammadiyah Purwokerto.

\section{REFERENSI}

1. Sudiro, M. \& Lestari, B.W. (2015) Prevalence of Allergic Rhinitis based on World Health Organization ( ARIA-WHO ) questionnaire among Batch 2010 Students of the Faculty of
Medicine Universitas Padjadjaran. Amj. 620625.

2. Ballenger JJ. (2003). Hidung Dan Sinus Paranasal. Dalam Staf Ahli Bagian THT RSCM FKUI (ed). Penyakit Telinga, Hidung, Tenggorok, Kepala Dan Leher. Edisi XIII. Jakarta : Biarupa Aksara.

3. Soepardi EA, Iskandar N, Bashiruddin J, Restuti RD. (2012). Buku Ajar Ilmu Kesehatan Telinga Hidung Tenggorok Kepala \& Leher Edisi 7. Jakarta: Fakultas KedokteranUniversitas Indonesia

4. Behbod, B., Sordillo, J.E., Hoffman, E.B., Datta, S., et al. (2015) Asthma and allergy development: contrasting influences of yeasts and other fungal exposures. Clinical \& Experimental Allergy. 45 (1), 154-163.

5. Allergic Rhinitis and its Impact on Asthma, 2008.ARIAGuidelines.http://www.whiar.org/ docs/ARIA_PG_08_View_WM.pdf. Mei2018 (15:00)

6. Ahmad, A., Husain, A., Mujeeb, M., Khan, S.A., et al. (2013) A review on therapeutic potential of Nigella sativa: A miracle herb. Asian Pacific Journal of Tropical Biomedicine. 3 (5), 337-352.

7. Nurjannah, N. (2011). Faktor Risiko Rinitis Alergi Pada Pasien Rawat Jalan Di Poliklinik THT-KL Rumah Sakit Umum Daerah Zainoe Abidin (RSUDZA) Banda Aceh Tahun 2011. Jurnal Kedokteran Syiah Kuala, 11(2), 60-65.

8. Shah S. (2012) Hormonal Link to Autoimmune Allergy. J of International Scholarly Research Network Allergy.

9. Sheikh, J. (2011). Allergic Rhinitis Medscape reference2. 1934-1944.

10. Garavello, W., Romagnoli, M., Sordo, L. Gaini, R.M., et al. (2003) Hypersaline nasa irrigation in children with symptomatic seasonal allergic rhinitis: a randomized study. Pediatric allergy and immunology. 14 (2), 140-143.

11. Suarez DL, Wood J, Taber P (2012) Adsorption and desorption of $\mathrm{B}$ in column studies as related to $\mathrm{pH}$ : Results and model predictions Vadose Zone 11:doi:10.2136/vzj2011.0073

12. Alsamarai, A., Abdulsatar, M. \& Alobaidi, A. (2014) Evaluation of Topical Black Seed Oil in the Treatment of Allergic Rhinitis. AntiInflammatory \& Anti-Allergy Agents in Medicinal Chemistry. 13 (1), 75-82.

13. Oysu, C., Tosun, A., Yilmaz, H.B., SahinYilmaz, A., et al. (2014) Topical Nigella sativa for nasal symptoms in elderly. Auris Nasus Larynx. 41 (3), 269-272.

14. Kanter, M., Coskun, O., \& Uysal, H. (2006). The antioxidative and antihistaminic effect of Nigella sativa and its major constituent, thymoquinone on ethanol-induced gastric 
mucosal damage. Archives of toxicology, 80(4), 217-224.

15. Wienkotter N, Höpner D, SchütteU, BauerK, Begrow F, ElDakhakhny M, et al. (2008) The effect of nigellone \& thymoquinone on inhibiting trachea contraction and mucociliary clearance. Plant Med; 74(2): 105-108.

16. Kim JC, et al. (2005) MKKS/BBS6, a divergent chaperonin-like protein linked to the obesity disorder Bardet-Biedl syndrome, is a novel centrosomal component required for cytokinesis. J Cell Sci 118:1007-1020.

17. Kalus, U., Pruss, A., Bystron, J., Jurecka, M., et al. (2003) Effect of Nigella sativa (black seed) on subjective feeling in patients with allergic diseases. Phytotherapy Research. 17 (10),1209-1214. 
TABEL

Tabsl 4.1. Distribusi nenyaringan subxuk dengan rinilis alerni.

\begin{tabular}{cccc}
\hline No & Ienis. & Exehuensi & Persentasi \\
& Kelaumit & & \\
\cline { 3 - 3 } 1 & Iak-Taki & 7 & $45 \%$ \\
2. & Perempuar & 8 & $55 \%$ \\
& TOTAL & $\mathbf{1 5}$ & $100 \%$
\end{tabular}

Iabcl 4.2. Walkty TMS scbclum dan scteleh terapi VaCin, $9 \%$

\begin{tabular}{cccc}
\hline NaCi 0.9\% & Rorata & $\begin{array}{c}\text { Standay } \\
\text { Deviasi }\end{array}$ & Pvahe \\
\cline { 2 - 4 } Scbelum & 7.582 & 1.574 & \\
Setelah & 5.879 & 3.237 & u.J. \\
\hline
\end{tabular}

Tabel 4.3. Waktu TMS sebelum dan setelah terapi Minyak Biji Jintan Hitam

\begin{tabular}{|c|c|c|c|}
\hline $\begin{array}{l}\text { Minxak Buit } \\
\text { Jistlan Hitam } \\
\text { Sebelum }\end{array}$ & Rerata & $\begin{array}{c}\text { Standar } \\
\text { Devidyi } \\
3.538\end{array}$ & Pvaliua \\
\hline Sctclah & 5.810 & 3.675 & 0,334 \\
\hline
\end{tabular}

Tahel 4.4. Perhandingan pennrunan wakth TMS valiakesluadoravi

$$
\begin{array}{lll}
\hline \text { Rali- } & \text { Standar } & P \\
1.206 & 3.3018 & 0.831 \\
1,284 & 2,618
\end{array}
$$

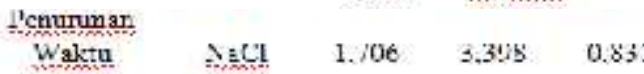$$
\text { (r) }
$$

\section{(т) ИвАК}

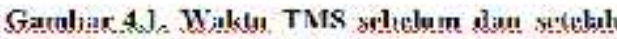
terapi NaCl 0,2\%

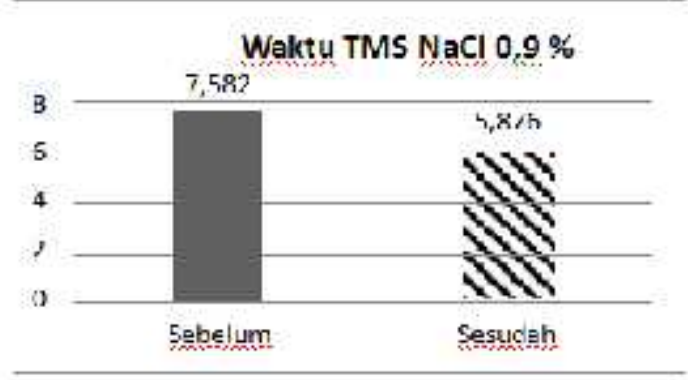

Gambar 4.2. Walktu TMS Scbclum dan sctelah terapi Minyak Biji Jintan Hitam

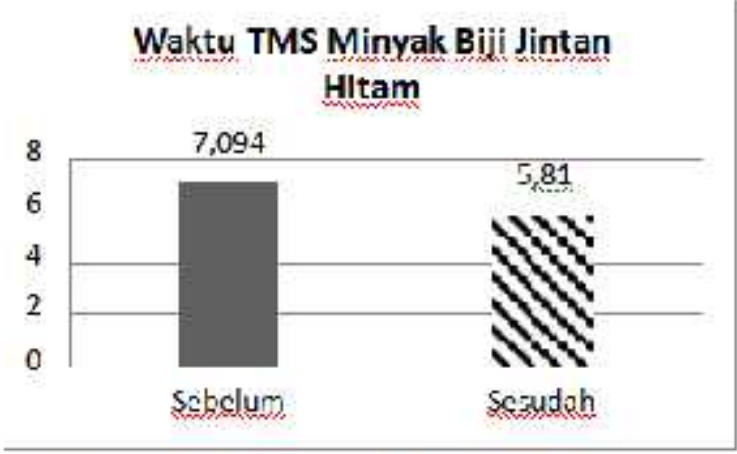

Gambar 4.3. Penurunan Waktu TMS pada kelompok terapi $\mathrm{NaCl} 0,9 \%$ dan Minsak Biji Jintan Hitam

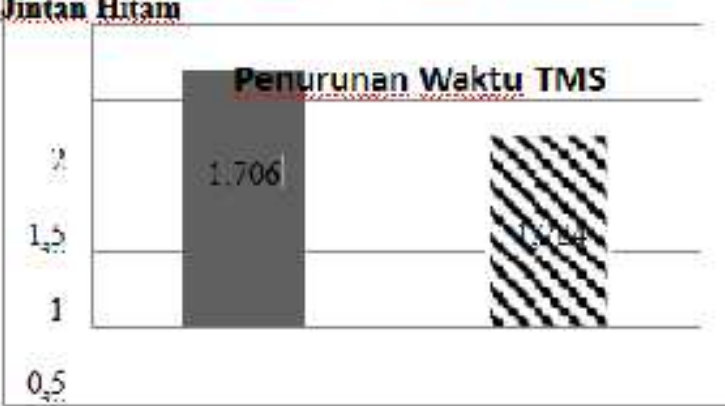

0

Nelio, $0,4 \%$ 